\title{
The Benefits and Constraints of the Use of Information and Communication Technology (ICT) in Teaching Mathematics
}

\author{
Nur Afiqah Zakaria, Fariza Khalid \\ Department of Learning \& Teaching Innovations, Faculty of Education, Universiti Kebangsaan Malaysia, Bangi, \\ Malaysia \\ Email: nurafiqah2903@gmail.com, fariza.khalid@ukm.edu.my
}

Received 7 June 2016; accepted 17 July 2016; published 21 July 2016

Copyright (C) 2016 by authors and Scientific Research Publishing Inc.

This work is licensed under the Creative Commons Attribution International License (CC BY).

http://creativecommons.org/licenses/by/4.0/

(c) (i) 0 pen Access

\begin{abstract}
The development of information and communication technology (ICT) has affected educators' teaching methods through its application in learning and teaching mathematics. The objective of this systematic analysis is to explore the benefits and constraints of ICT that have been faced by educators during learning and teaching processes for mathematics. Based on selected literature, it was found that the advantages of applying ICT in teaching mathematics are: It attracts students' interest in learning mathematics; it increases their motivation and performance; it encourages lifelong learning; and it facilitates positive interactions and relationships. Nevertheless, a few constraints have been faced by mathematics educators during teaching processes involving ICT. Identified constraints and limitations are: Educators lacking knowledge of ICT; minimal training and opportunities for learning about ICT; and limited technical support. Therefore, it is suggested in the literature that there is a need for an increase in training for mathematics educators in terms of computer usage and ICT applications for teaching purposes. Technical support should also be a concern, so as to motivate mathematics educators to apply elements of ICT in their teaching. This could maintain the positive changes and perception of students regarding learning mathematics.
\end{abstract}

\section{Keywords}

Advantages of ICT, Integration of ICT, Teaching Mathematics, Hindrances of ICT, Mathematics

\section{Introduction}

Information and Communication Technology (ICT) is a combination of devices and technology resources, which are used to manipulate and correlate information (Kaware \& Sain, 2015). Technology tools cover all

How to cite this paper: Zakaria, N. A., \& Khalid, F. (2016). The Benefits and Constraints of the Use of Information and Communication Technology (ICT) in Teaching Mathematics. Creative Education, 7, 1537-1544. 
electronic and digital devices such as computers, the internet, and other multimedia technology. The usage of ICT is becoming more crucial in education as it enables the development of a more proactive teaching and learning environment (Gabare et al., 2014, Daud \& Khalid, 2014). Together with the expansion of current era of technology, educators are encouraged to incorporate ICT into their teaching, as a substitute for traditional teaching methods (Kiflee \& Khalid, 2014).

ICT is not only a tool for teaching and learning, but also acts as a driving force for an educator to play his or her role in education (Nur Qistina \& Hazman, 2006). For example, the application of ICT could expose students to various skills linked to their future needs, such as using Microsoft Word, email, and the internet for lifelong learning processes (Gabare et al., 2014; Khalid, 2014; Jones, 2011). Furthermore, the application of ICT can help educators to obtain resources from outside their networks, thus enabling them to transform the teaching and learning process.

The application of ICT is intended to refine and elevate both students' learning and educators' teaching qualities (KPM, 2013). In addition, it is a process of fitting technology to various learning and teaching conditions, whether inside the classroom or outside (Norazrena \& Khairul Anuar, 2011; Nur Qistina \& Hazman, 2006). Moreover, the integration of ICT in education could increase students' competence based on global needs through skill shaping and increasing knowledge (Storm, 2011), as well as able to enhance students' cooperative learning through community of practice (Khalid et al., 2013, 2014).

ICT could be applied to all subjects, including mathematics. According to Keong et al. (2005), 89.5\% of mathematics educators use basic ICT applications in their teaching. These basic applications include training software, visuals and graphics, and online demonstrations. These applications function as teaching aids in mathematics. This shows educators' ICT skills have increased in applying various technological applications to their teaching process (Wan Mohd, 2013).

Furthermore, research shows that internet searches through websites are used by $68.5 \%$ of mathematics educators, while email is used by $44 \%$, and $7.2 \%$ participate in online forum discussions (Keong et al, 2005). These percentages relate to educators' ability to apply ICT in order to access teaching resources other than textbooks. Indirectly, ICT has become an important means for educators to acquire teaching resources in the form of simulations, notes, exercises, brainstorming, and information sharing.

Other research shows that technological integration in teaching mathematics includes the use of Microsoft Excel, DERIVE, MATHEMATICA, and MAPLE software for algebra (Keong et al., 2005; Neurath \& Stephens, 2006). The use of Microsoft Excel facilitates students to carry out algebra-related problem-solving, such as constructing equation graphs, finding the slope of a straight line, and simplifying equations. MAPLE is also used to aid students in constructing equation graphs in algebra.

Learning software is also being developed based on certain topics in mathematics. For instance, the development of computer-based software for the topic of fractions is based on the ASSURE learning model. In addition, mathematical software for special education students is constructed based on the ADDIE learning model. Both of these types of software function as a medium for additional exercises and to acquire notes for the topic of fractions. Students are able to repeat exercises multiple times and obtain direct feedback from the website (Norazrena \& Khairul Anuar, 2011).

\section{Applications of ICT in Mathematics}

There are some applications of ICT that have been used by teachers in the teaching and learning of mathematics, whether for secondary schools or for primary schools. These applications act as teaching aids for teachers and revision materials for students, either during the lessons in schools or at home. ICT applications also help students in doing their assignments for mathematics.

Norazrena and Khairul (2011) developed computer-based software for teaching and learning the topic of fractions. The software was developed based on the ADDIE model, which stands for Analysis, Design, Develop, Implement, and Evaluation. This study was conducted in a secondary school for students with special needs. The content of the software is based on the basic concepts of fractions, which include proper fractions, and addition and subtraction of fractions. In addition, the software developed for the study focused on special needs students in Form 1. The results show that achievements of the participants increased after they used the software that was implemented during the learning process. The software decreased the cognitive load during their learning because its content used simple examples that were clearly explained. This successful development is also effective for non-special needs students to improve their knowledge of the basic concepts infractions. 
Hanim and Hairulniza (2002) also created mathematical software based on the ASSURE model for fractions in the Form 1 syllabus. The ASSURE model involves six stages of development, which are Analysis, State objectives, Select method, materials and media, Utilise the materials, Require learners' response, and Evaluation. This software acted as a medium for tutorials in fractions, including all operations in fractions such as multiplication, division, addition and subtraction. It gave spontaneous feedback on students' exercises and made the learning process more interactive (Hanim \& Hairulniza, 2002). Tests were also prepared for all subtopics to improve students' knowledge about the topics. Participants enjoyed the learning process using this software. It also enhanced students' behaviour and critical thinking regarding this topic.

In addition, Neurath and Stephens (2006) used Microsoft Excel as a teaching aid for algebra class. They conducted a study in a secondary school through experimental research. Traditional methods of teaching were delivered to a control group, while the experimental group was taken to a computer laboratory and were shown various problems and how to solve them using Microsoft Excel. Three comprehensive tests were given to both the control group and the experimental group, involving the same questions. They found a slight increase in students' achievements and in their interest in the topic among the experimental group. They enjoyed the Excel assignments and increased their overall understanding of algebra, which blended well with computers and technology.

Meanwhile, Stephen and Konvalina (2006) conducted another study on the effectiveness of the MAPLE program in algebra. They also conducted research in a secondary school. This study found that MAPLE increased the positive attitude of students with regard to algebra. Stephen and Konvalina also conclude that the MAPLE program increased students' achievements by $5 \%$ when MAPLE was used to complete algebra assignments. Furthermore, it was shown that for students who chose to complete their assignments using MAPLE, their achievements on their final exams were improved.

In summary, past research has been done on the integration of ICT into mathematics teaching, for example using Microsoft Excel, computer-based software and the MAPLE program. Nevertheless, the extent to which the application of these forms of technology is proven to enhance mathematics learning amongst students and the constraints faced need to be further explored. This paper, hence, has two objectives: To explore the benefits of integrating ICT into teaching and learning mathematics at primary and secondary school levels, and to identify the limitations faced in efforts to integrate ICT into teaching and learning mathematics.

\section{Methodology}

The research highlights research studies conducted in the field of applying ICT in teaching mathematics. Multiple databases (Emerald, Google Scholar, Sci Direct, and EBSCOhost) were explored, using keywords such as: Integration of ICT; ICT in mathematics; and ICT and constraints. The literature chosen was in the two languages that can be understood by the researcher, which are Malay and English. In addition, the search was limited to studies published between 2001 until 2015 related to ICT in education.

More than 300 studies were found. However, only 20 studies from Malaysia and abroad were selected, based on the research focus on ICT in mathematics education. The selected studies were chosen based on the context of studies, scope, and the respondents involved. Figure 1 summarizes the selection process of the previous studies.

Table 1 indicates the summary of the selected studies in terms of the methodology, location, research focus, and area of research.

The selection of literature was based on the need to answer the research questions constructed. In addition, content analysis was carried out in order to ensure that the selected literature did not divert from the focus of this concept paper.

Table 1. Summary of the 20 studies used.

\begin{tabular}{|c|c|c|c|c|}
\hline Experimental design & Location & Research focus & Area & Application of ICT \\
\hline Qualitative (8) & Malaysia (12) & Educators (9) & Information technology (12) & Computer-based software (10) \\
\hline Quantitative (6) & United Kingdom (4) & Students (10) & Mathematics (8) & Graphing software (2) \\
\hline Quasi experiment (1) & USA (2) & Schools (1) & & Microsoft Excel (4) \\
\hline \multirow[t]{2}{*}{ Concept paper (5) } & Other (2) & & & MAPLE (1) \\
\hline & & & & iPad (1); Other (2) \\
\hline
\end{tabular}




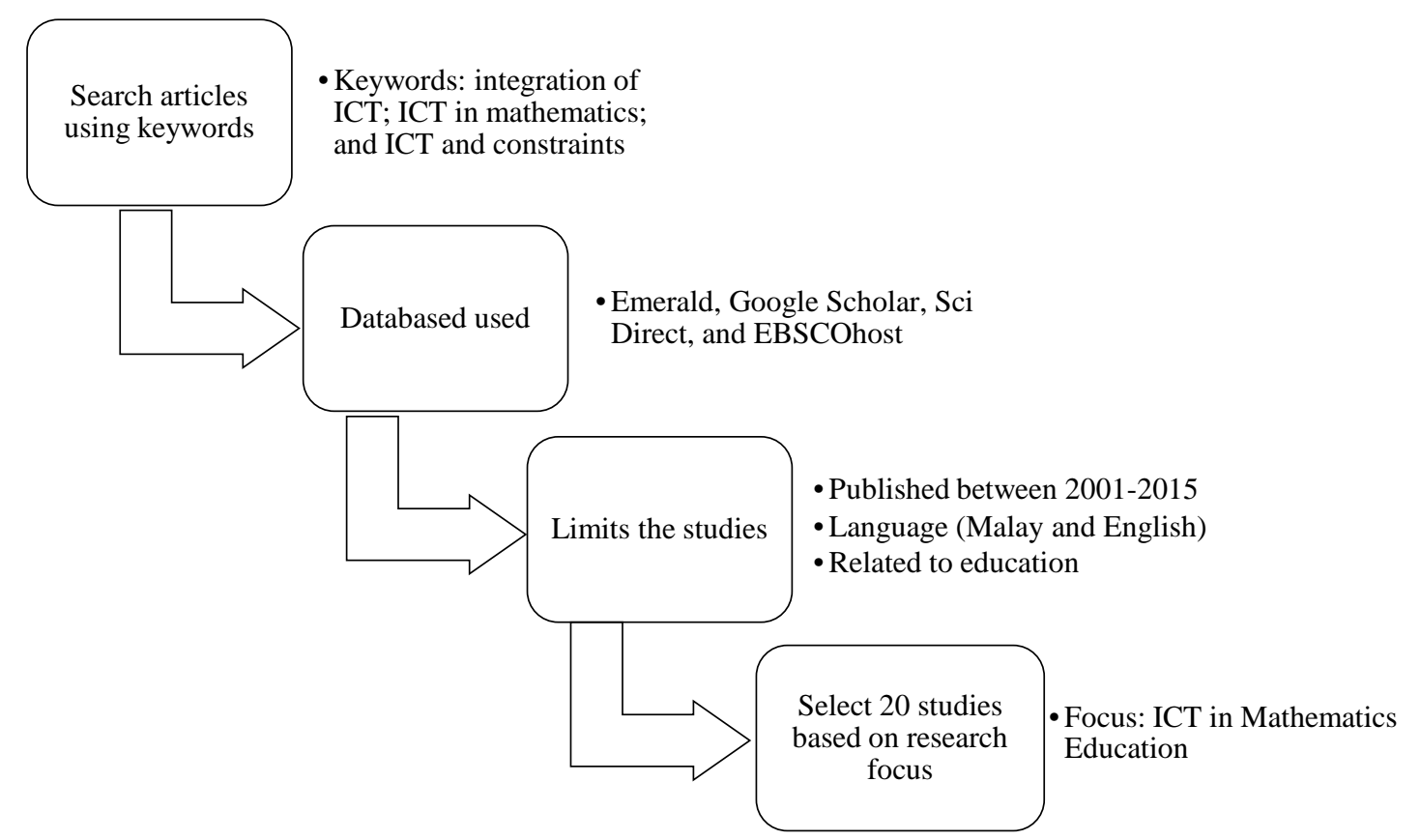

Figure 1. The selection process of previous studies.

The research questions are:

1) What are the benefits of applying ICT in the learning and teaching of mathematics?

2) What are the constraints faced by educators in integrating ICT into teaching mathematics?

The research questions were constructed to focus the literature review on track and to facilitate the analysis of the literature. For the first question, the literature studied is focused on the benefits of applying ICT in the teaching and learning of mathematics for teachers and students. For the second question, the literature studied is focused on the constraints faced by educators in using technology during the process of learning and teaching mathematics.

\section{Result and Discussion}

The research findings are arranged according to the research questions.

\subsection{The Benefits of Applying ICT to Learning and Teaching Mathematics}

Based on the literature review, one of the benefits of applying ICT in the teaching of mathematics is creating interaction among students (Keong et al., 2005; Neurath \& Stephens, 2006). The use of technological devices such as graphing calculators encourages interaction among students to share their knowledge and skills. The findings from two studies indicate that cooperation among students occurred when they were given the opportunity to present their work with the aid of a projector, a screen and a laser pen. Students shared their work with classmates in discussion sessions with the help of teachers (Condie \& Munro, 2007; Keong et al., 2005).

Indirectly, the communication that occurred among students through the application of technology during the learning process promoted knowledge and information-sharing. Educators acted as facilitators, while the learning process that occurred with the help of technology as a learning tool was student-centred (Condie \& Munro, 2007; Keong et al., 2005). This supports constructivist learning, which is the construction of students' knowledge. The application of technologies such as the internet further facilitates students' self-exploration, for example using the internet to understand mathematical concepts learned (Keong et al., 2005; Ramli et al., 2006).

The application of information technology can also increase students' motivation and interest towards mathematics. This was evident when students' results in algebra improved (Keong et al., 2005; Neurath \& Stephens, 2006). The use of Microsoft Excel in learning algebra can change students' perceptions of algebra. Students are eager to perform tasks with the aid of Excel, and indirectly the learning process becomes meaningful to students. 
The same study found that students admitted to having an increased understanding of algebra with the help of computers.

The same was found with regard to the usage of computer software for fractions, as examined in two of the selected studies (Hanim \& Hairulniza, 2002; Norazrena \& KhairulAnuar, 2011). The computer software developed greatly assisted students in improving their understanding of fractions. The exercises provided by the software gave students direct feedback. Hence, students were able to identify their mistakes and make corrections (Ghavifekr et al., 2012). In addition, the menu quiz developed within the computer software helped students to hone their critical thinking. This is because the quiz provided had a limited response time. The time limit was set to test students' critical thinking and their understanding of the fractions topics learned.

Three other studies showed that the application of ICT in learning not only generates higher-level thinking skills among students, but also encourages students to think about strategies in solving mathematics problems (Condie \& Munro, 2007; Keong et al., 2005). In addition to giving students prompt responses, the computer software developed encouraged students to do exercises repeatedly until the correct answers were obtained. Indirectly, this approach increases students' interest and motivation to keep trying.

\subsection{Constrains Faced by Educators in Integrating ICT into the Teaching of Mathematics}

Despite the advantages resulting from the integration of ICT into learning processes in mathematics, some constraints are faced by educators in the implementation of ICT. Among the constraints faced by educators are reduced teaching time in the classroom, insufficient training on the application of ICT, weak technical support, limited resources for students when at home, and limited pedagogical knowledge on how to integrate ICT into teaching (Afolake \& Shittu, 2005; Keong et al., 2005).

The limited time for teaching mathematics in the classroom has become the main limiting factor for educators when integrating ICT into their teaching (Keong et al., 2005). The literature shows that 55.6\% of 111 respondents (educators) recognized the time limitations in the school's teaching schedule for them to use ICT facilities. These time limitations include the need to prepare the equipment before starting the learning process. This could include computer equipment, screens, projectors and others, which take time to set up, as educators are unused to handling these tools (Rohani, 2011). In case of damage or minor difficulties, educators require assistance from technicians, which further interferes with their teaching time.

$40.8 \%$ of teachers stated that they had received insufficient training on the application of ICT to ease teaching the mathematics curriculum. The training required includes methods of integrating ICT into teaching mathematics. Furthermore, 59.5\% of teachers admitted that several types of training on ICT applications were needed, in order for them to identify the appropriate applications for the teaching and learning of mathematics (Abramovich, 2014; Afolake \& Shittu, 2005). Training should be conducted periodically and should meet the need of mathematics educators so that it is useful in practice.

A lack of technical support for the integration of ICT into the teaching of mathematics is also a limiting factor for educators. Problems in technical support include the provision of limited computers for students, damaged equipment which take a very long time to be repaired, booking procedures for computer labs, and educators' limited computer skills. $39.2 \%$ of educators identified these factors as a major constraint, while $46.4 \%$ indicated these factors as minor constraints. However, the technical support factor strongly influenced the frequency of educators integrating ICT into their teaching.

Another factor that becomes an obstacle in the implementation of ICT in the teaching of mathematics is limited technological resources when teachers or students are at home. $78.4 \%$ of educators admitted that their students do not have good access to the necessary technology to facilitate learning at home. For students who do not have computers and internet access, learning through ICT applications will be limited to school only (Keong et al., 2005; Ruthven et al., 2009). Similarly, educators who do not have access to the necessary technology will be impeded in their preparation of teaching materials for mathematics. $76.3 \%$ of educators recognised this factor as a constraint to integrating ICT into their teaching and learning process.

In addition to the factors listed above, there are also minor constraints that hinder teachers from applying ICT in their teaching of mathematics. Among these are insufficient computer software, ICT integration not being a priority for the school, and difficulties in attending training on ICT skills (Afolake \& Shittu, 2005; Palmer, 2003). Due to these multiple factors, the implementation of ICT in the teaching of mathematics can become less effective and receive a lack of support among educators. 
Based on the findings described above, the following is a summary of the benefits and limitations of applying ICT to the learning of mathematics (Figure 2).

Based on a synthesis of the literature, the use of technology in teaching is shown to have a favourable impact on both students and educators (Rafiza \& Maryam, 2013). In the context of teaching mathematics, previous studies have found that technology is a necessity in the process of learning and teaching mathematics in schools. It has been proven that ICT can improve mathematics teaching methods, as well as elevating students' understanding of basic mathematical concepts. Information technology is also proven to harbour potential in preparing students for twenty-first century life (Ghavifekr et al., 2012). Through developing skills in ICT, students will be better prepared to face future challenges by understanding them better.

However, educators should be ready to face obstacles and constraints so that these hindrances should not be limitations in integrating ICT into teaching mathematics. Various methods and strategies should be well thought out by educators in order to implement more interesting teaching approaches through the integration of ICT (Drew, 2011). The development of increasingly diverse technologies assists educators in using initiative to access "extra" exercises regarding the use of technology. In addition to the convenience of the internet, educators can also utilise the medium of virtual storage (Cloud storage) as an alternative initiative for the integration of ICT into teaching.

For example, Google apps such as Google Slides, Google Docs, and Google Sheets can be utilised by educators for teaching mathematics. These applications can be shared online via Google Drive (Suzana \& Khalid, 2014). Students and educators can interact directly when both parties access the internet at the same time. These applications enable educators to give direct feedback through comments and notes sections. In addition, students who missed the opportunity to access the internet at a particular point can still participate by looking at the changes that are shared through the history menu. Thus, learning can take place anywhere and at any time.

The development of technology in the twenty-first century has produced a variety of teaching equipment that allows educators to share information at their fingertips. In addition to Google Drive, application including Powtoon, Piktochart, StoryBoardThat, PresentMe, Cantasia, Prezi and others are capable of producing teaching materials that attract students' interest to engage in interactive learning.

Moreover, schools should review the need to facilitate the application of ICT in classroom teaching. Technical support is crucial in learning in tandem with technological developments. In addition to providing technical expertise to educators, basic ICT facilities should also be provided. This will boost educators' morale in employing the use of ICT in their teaching. Indirectly, students will become more motivated and excited about learning mathematics, due to the use of new and creativity techniques.

One issue that can be highlighted in future research is the effectiveness of the implementation of various ICT applications for student understanding. Besides, educators' ICT skills and teaching pedagogy can also be promoted as helping teachers believe that ICT can facilitate teaching as well as boost morale for students. The interest and motivation of students toward learning will increase if the teaching methods are not boring and provide interesting inputs each time the learning process occurs. Further studies on students' perceptions of computer-aided learning are also encouraged in order for educators to identify computer software or technology that suits the teaching of mathematics in schools.

\begin{tabular}{|l|l|}
\hline \multicolumn{2}{|c|}{ Application of ICT in learning mathematics } \\
\hline \multicolumn{1}{|c|}{ Benefits } & \multicolumn{1}{|c|}{ Constraints } \\
\begin{tabular}{l|l} 
1. Interaction among students \\
2. Knowledge-sharing \\
3. Increased motivation and interest \\
4. Generation of higher-level \\
thinking skills \\
5. Increased student achievement
\end{tabular} & $\begin{array}{l}\text { 1. Limited teaching time } \\
\text { 2. Insufficient training } \\
\text { 3. Lack of technical support } \\
\text { 4. Limited resources when students are } \\
\text { at home } \\
5 . \text { Lack of pedagogical knowledge }\end{array}$ \\
\hline
\end{tabular}

Figure 2. Summary of benefits and constraints regarding the application of ICT to learning mathematics. 


\section{Conclusions}

Based on the synthesis of the 20 selected pieces of literature, it was found that the benefits of applying ICT in the teaching of mathematics include attracting students' interest in learning mathematics; improving students' performance; encouraging lifelong learning; enabling positive interactive relationships; and supporting constructivist learning. However, several constraints have been faced by mathematics educators in involving ICT in the teaching process. The constraints identified include educators' lack of knowledge about technology; minimal training and learning opportunities around ICT; and limited technical support.

Accordingly, it is proposed that there should be an increase in the amount of training available for mathematics teachers concerning the use of computers and the application of ICT for teaching purposes. Technical support is also needed in order to motivate teachers to implement ICT in their teaching. This is required to maintain students' positive perception of learning mathematics. It is also suggested that educators explore in order to determine the appropriate technologies and applications that can be integrated into the mathematics teaching and learning process.

\section{References}

Abramovich, S. (2014). Revisiting Mathematical Problem Solving and Posing in the Digital Era: Toward Pedagogically Sound Uses of Modern Technology. International Journal of Mathematical Education in Science and Technology, 1, 1-19. http://dx.doi.org/10.1080/0020739x.2014.902134

Afolake, N., \& Shittu, A. J. K. (2005). Evaluating the Impact of Technology Integration in Teaching and Learning. The Malaysian Online Journal of Educational Technology, 2, 23-29.

Condie, R., \& Munro, B. (2007). Anlayse Impact of ICT on Learning and Teaching. In L. Seagraves, \& S. Kenesson (Eds.), The Impact of ICT in Schools-A Landscape Review. Glasgow: University of Strathclyde.

Daud, M. D., \& Khalid, F. (2014). Nurturing the 21st Century Skills among Undergraduate Students through the Application and Development of Weblog. International Education Studies, 7, 123-129. http://dx.doi.org/10.5539/ies.v7n13p123

Gabare, C., Gabarre, S., Din, R., Shah, P. M., \& Karim, A. A. (2014). iPads in the Foreign Language Classroom : A Learner's Perspective. The Southeast Asian Journal of English Language Studies, 20, 115-128. http://dx.doi.org/10.17576/3L-2014-2001-09

Ghavifekr, S., Razak, A., Ghani, M. A., Ran, N. Y., Meixi, Y., \& Tengyue, Z. (2012). ICT Integration in Education: Incorporation for Teaching \& Learning Improvement. The Malaysian Online Journal of Educational Technology, 2, 24-45.

Hanim, S., \& Hairulniza, Z. (2002). Pembangunan Perisian Pembelajaran Berpandukan Komputer (PBK) Bagi Tajuk Pecahan Tingkatan Satu Berdasarkan Model Pembelajaran ASSURE. Jurnal Teknologi Pendidikan Malaysia, 34, 121-130.

Jones, P. H. (2011). The Impact of Digital Technologies on Human Wellbeing. In D. Sutch (Ed.), Evidence from the Sciences of Mind and Brain, United Kingdom: Nominet Trust.

Kaware, S. S., \& Sain, S. K. (2015). ICT Application in Education: An Overview. International Journal of Multidisciplinary Approach and Studies, 2, 25-32.

Kementerian Pelajaran Malaysia, KPM (2013). Laporan Awal-Ringkasan Eksekutif: Pelan Pembangunan Pendidikan Malaysia 2013-2025.

Keong, C., H. Sharaf, H., \& Daniel, J. (2005). A Study on the Use of ICT in Mathematics Teaching. Malaysian Online Journal of Instuctional Technology (MOJIT), 2, 43-51.

Khalid, F. (2014). Students' Views on the Use of e-Portfolio and Support Given to Promote Their Computer Learning for Educational Purposes. Recent Advance in Telecommunications, Informatics and Educational Technologies, 1, 54-59.

Khalid, F., Joyes, G., Ellison, L., \& Abdul Karim, A. (2013). Teachers’ Involvement in Communities of Practice: An Implication with Regard to the Current Approach of Teachers' Professional Development in Malaysia, Asian Social Science, 9, 102-111. http://dx.doi.org/10.5539/ass.v9n16p102

Khalid, F., Joyes, G., Ellison, L., \& Daud, M. D. (2014). Factors Influencing Teachers’ Level of Participation in Online Communities. International Education Studies, 7, 23-32. http://dx.doi.org/10.5539/ies.v7n13p23

Kiflee, C. S., \& Khalid, F. (2014). Keberkesanan Kaedah Multimedia dalam Pengajarandan Pembelajaran Terhadap PelajarPintar. In F. Khalid (Ed.), International Seminar on Global Education II: Education Transformation towards a Developed Nation (pp. 135-159). Bangi: Fakulti Pendidikan, UKM.

Neurath, R. A., \& Stephens, L. J. (2006). Classroom Notes the Effect of Using Microsoft Excel in a High School Algebra Class. International Journal of Mathematical Education in Science and Technology, 37, 721-727.

Nur, Q., \& Hazman, A. (2006). Penggunaan Teknologi Maklumat dan Komunikasi (ICT) dalam Kalangan Guru-Guru Sekolah Kebangsaan. Thesis, Johor Bahru: Universiti Teknologi Malaysia. 
Palmer, C. (2003). Using ICT in Mathematics Helping or Not? In R. Hudson (Ed.), Mathematics Teaching (pp. 9-11). Association of Teachers of Mathematics.

Rafiza, A. R., \& Maryam, A. R. (2013). Pembinaan Media Pengajaran berasaskan Multimedia di kalangan Guru ICTL. Jurnal Kurikulum \& Pengajaran Asia Pasifik, 1, 20-31.

Ramli, B., Latifah, A. L., Noor, A. I., \& Abd Rahman, N. N. N. (2006). The Impact of "Learning Skills for Open and Distance Learners” Course on Learner Attitudes towards E-Learning. In R. Bahroom, L. Abdol Latif, N. Azina Ismail, \& N. N. N. Abd Rahman (Eds.), Konvensyen Teknologi Pendidikan ke 19, Langkawi (pp. 1055-1063). Selangor: Open University Malaysia.

Ruthven, K., Deaney, R., \& Hennessy, S. (2009). Using Graphing Software to Teach about Algebraic Forms : A Study of Technology-Supported Practice in Secondary-School Mathematics. Educational Studies in Mathematics, 71, $279-297$. http://dx.doi.org/10.1007/s10649-008-9176-7

Storm, M. (2011). Cognitive Development: Cognitive Development (2nd ed., pp. 17-25). Amerika: American Institutes for Research.

Suzana, S., \& Khaild, F. (2014). Pengajaran dan Pembelajaran Menggunakan Perisian Google—Satu Analisis Kajian Lepas. In F. Khalid (Ed.), Pengajaran Sumber dan Teknologi Maklumat: Impaknya ke atas Penyelidikan dalam Pendidikan (Vol. 1, pp. 25-32). Bangi: Fakulti Pendidikan, UKM.

Wan Mohd, R. (2013). Penerapan Teknologidalam Pendidikan: MAMPU. Kolokium ICT dalam Pendidikan 2013: “Kepimpinan Pengurusan ICT dalam Pendidikan Abad ke-21”. Institut Aminuddin Baki.

\section{Submit or recommend next manuscript to SCIRP and we will provide best service for you:}

Accepting pre-submission inquiries through Email, Facebook, LinkedIn, Twitter, etc.

A wide selection of journals (inclusive of 9 subjects, more than 200 journals)

Providing 24-hour high-quality service

User-friendly online submission system

Fair and swift peer-review system

Efficient typesetting and proofreading procedure

Display of the result of downloads and visits, as well as the number of cited articles

Maximum dissemination of your research work

Submit your manuscript at: http://papersubmission.scirp.org/ 